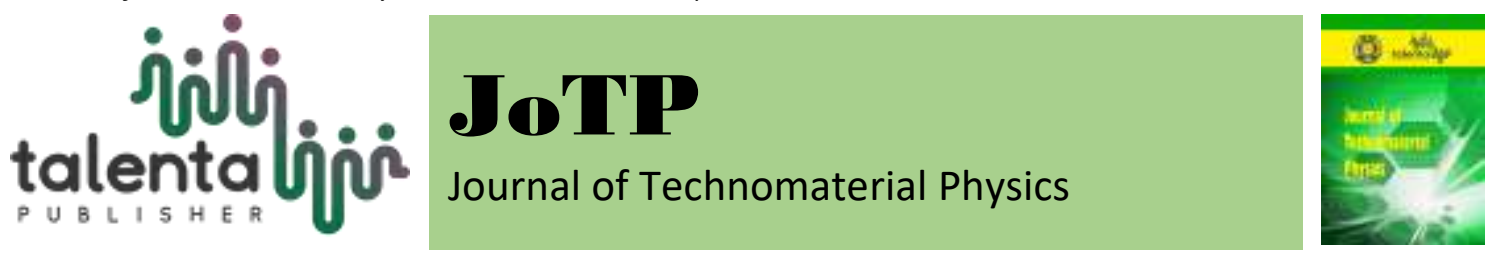

\title{
The Production of Rencong Souvenir Based on Reused Brass Metal Waste
}

\author{
Ahmad Farhan ${ }^{1}$ and Akhyar ${ }^{2}$ \\ ${ }^{1}$ Department of Physics Education, Faculty of Teacher Training, University of Syiah Kuala, Darussalam, \\ Banda Aceh, Indonesia 23111 \\ 2 Department of mechanical engineering, University of Syiah Kuala, Jalan Tgk. Krueng Kale No. 7 \\ Darussalam Banda Aceh Indonesia, 23111
}

\begin{abstract}
The Traditional metal forming in fabricating rencong as souvenir requires high demands of energy, time, and accuracy skills from the blacksmith, but the quality that has been obtained is quite low, which includes colors diversity, and non-uniformity of brightness. The raw materials of brass metal are importantly needed for manufacturers, so that the cost of productions is relatively expensive. This study aims to improve the technology for fabricating rencong souvenir, which is expected to increase the production efficiency as well as conserving and improving the cultural and economic sectors. The simple casting techniques were conducted to be taught to the craftsmen from designing, mold and field training. This technology was able to be adopted very well by the craftsmen, while the rencong blades were produced in large scale by utilizing the brass metal waste. The diversity of sizes and shapes were obtained in small size and shapes blades, and the uniformity of color brightness was produced, so that the quality of souvenirs increases. Thus, the application of this technology can increase the income of craftsmen and the quality of souvenirs.
\end{abstract}

Keyword: Souvenirs, rencong, foundry

Received 26 April 2019 | Revised [12 August 2019] | Accepted [31 August 2019]

\section{Introduction}

The campaign of "Visit Aceh 2017" which has been published by the Government of Aceh Province becomes one of the motivations for craftsmen in Aceh, in particular to produce rencong as souvenirs. The production of rencong has been conducted by using metal forming, which brass bars are heated to be melted, so that these bars can be crafted to expected shapes by smacking. The disadvantages of this technology are the sufficient process as it requires high skills of crafting the size and shape of rencong. Although the rencong is produced in high precision shapes, the cost of production is high due to the time requirements in finishing one product. To produce a blade of rencong, seven to eight days are needed by the craftsmen to

\footnotetext{
*Corresponding author at: Faculty of Teacher Training, University of Syiah Kuala, Darussalam, Banda Aceh, Indonesia 23111

E-mail address: farhanfis@unsyiah.ac.id; akhyar@unsyiah.ac.id
} 
produce. Another social issue is the inheritance of fabrication of rencong traditionally since the young generation is not interested in continuing this tradition.

Therefore, new technology in metal forming must be applied to improve the production of the souvenirs, so that it also can increase the local income for the craftsmen. There are two aspects that require serious issues, and they are the efficiency of production and the quality of rencong itself.

Metal forming technology producing the rencong souvenirs have been considered promising to be applied. This is because of several advantages such as small amount of energy based on human, low requirements of craftsman skills, efficient productions by using the metal brass waste with large scale fabrications. On the other hand, the results of production have high uniformity regarding to the sizes, shapes, colors, and brightness.

However, metal casting and smelting involves high temperature inside a suitable furnace [1-3]. In addition to start the casting, types of stoves and fuels have been studied such as the use of crucible furnace heated by Liquid Petroleum Gas (LPG) in melting the aluminum metals at $600^{\circ} \mathrm{C}$ [4-7] and. It also has been reported that a furnace supported by kerosene was able to melt aluminum metals with $30 \mathrm{Kg}$ of capacity [8]. Meanwhile, Magga [9] has reported that the use of charcoal from wood can be used effectively to melt brass inside a metal furnace.

According to the previous explanations, a program that converts traditional metal technology to modern casting technology in addition to improve the productivity of rencong is conducted in Baet Lampuot Village, District of Aceh Besar, Aceh Province. An integrated program in improving the technical skills of the craftsmen which mainly graduated from primary and secondary schools are required too. Nevertheless, this will facilitate the transfer of technology. The workshop is also needed to be designed due to the conversion of fuel in operating the casting process with easy access of fuel by the craftsmen, so that it can be operated in efficient, affordable, and effective stages.

\section{Materials and Methods}

\subsection{The Implementation of Criteria Technology}

As the human resources skills are relatively limited, the transfer technology in producing the rencong souvenirs efficiently and effectively, three aspects need to be implemented. They are:

a. The technology used is simple casting metal technology

b. The raw materials to produce blades of rencong is metal brass waste

c. The fuel in melting the metal inside a furnace utilizes wood charcoal 


\subsection{The Designing of Melting Metal Furnace}

The furnace was designed based on the Magga [9], integrated by wood charcoal as the main fuels. The following Figure 1 illustrates the design of the furnace. And based on the field observations, and technical analysis due to the safety, convenience, and economic aspects, the specifications of the furnace were determined as:

a. Outer dimension of the furnace is $50 \times 50 \times 40 \mathrm{~cm}$

b. The furnace was made of by medium steel

c. The heat within the pyrolysis vessels was protected by fire-resistant stones, silica sand bonded by heat-resistant cement

d. The ladle which was used as a media to poured the liquid metal into the mold was composed by stainless steel

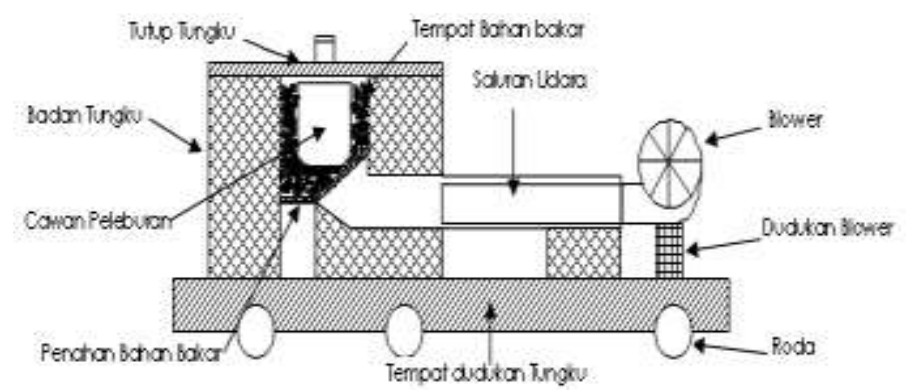

Figure 1. The model design of a melting furnace fuelled by charcoal

\subsection{Mold}

The mold was designed by carbon steel with six specimens consisted by ascending sizes from small to big sizes. The size was designed based on the demands of the rencong souvenir craftsmen. The manufacture of casting of the metal molds was made accordingly to the shape of rencong based on six cavities, which can be used to produce six rencong blades within one pour (with different sizes for each cavity).

\subsection{Transfer of technology}

The activities of transferring technology were conducted by two stages. The first stage was the socialization of transfer technology including the instruments and raw materials used, work principle of the furnace, and occupational health and safety that needs to be considered primarily. The next stage was conducted by providing live techniques of simple metal casting to the craftsmen. 


\subsection{Finishing processes}

The processes are adopted by previous techniques conducted by the craftsmen. This is based on the considerations which were not the main factors in slowing the efficiency of productions of rencong souvenir. These processes involved mainly to female workers which have been socialized and implement very well by the craftsmen. Therefore, manual finishing processes are considered to be maintained. The finishing process steps are hand-crafting smoothing by sandpaper, and the use of metal shiny solutions in polishing.

\section{Result and Discussion}

The design and fabricating the metal casting furnace (Figure 2a) used have been operated very well by the craftsmen. The size of the metal furnace is suitable to be applied to the society, while the heat resulted was able to melt the brass metal waste. The utilization of crucible workshop with sand casting techniques fueled by the charcoal has been effectively operated with good-quality of products [10-15].

The mold in fabricating the blades of rencong which was made by medium carbon steel (Figure 2b) was able to hold the brass metal waste within melting point [16-18]. Therefore, the mold could be used repeatedly without changing the physical properties. Nonetheless, the training process of melting and casting of metal brass have been conducted according to the plans.

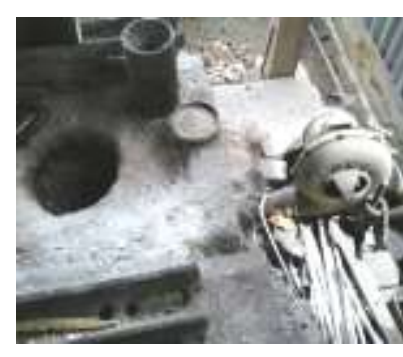

(a)

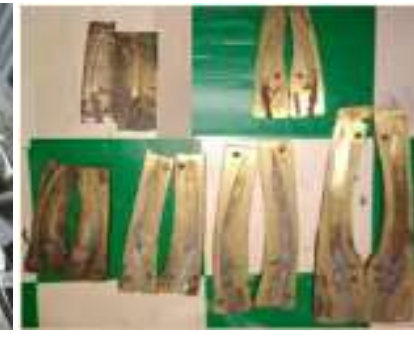

(b)

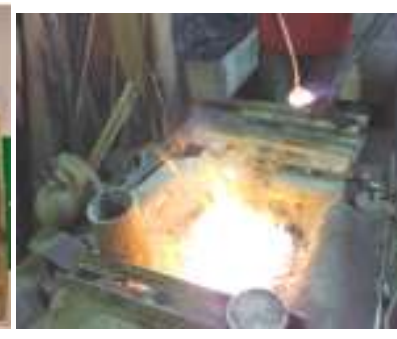

(c)

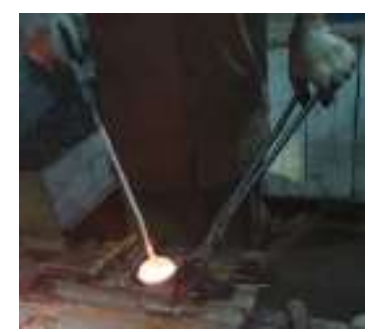

(d)

Figure 2. The designs of furnace and mold to produce rencong souvenir

The simple casting technology [19-20] method was implemented to the craftsmen which was able to adopt very well. The craftsmen proceeded without difficulties in these practices. The Figure $2 \mathrm{c}$ and $2 \mathrm{~d}$ illustrated the process of casting conducted by the craftsmen to produce rencong blades. The socialization techniques were done relatively in short amount of time, and 
Journal of Technomaterial Physics Vol. 1, No. 2, 2019 | $125-131$

the craftsmen were skillfully and quickly to understand in operating the casting tools. These are caused by the simplicity of the casting technology, and the experiences in casting the rencong by metal casting technology.

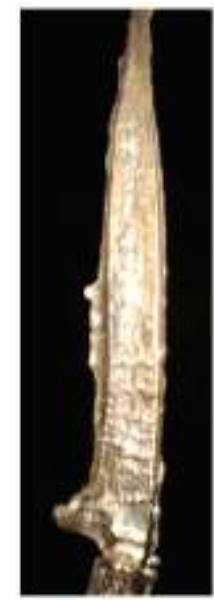

(a)

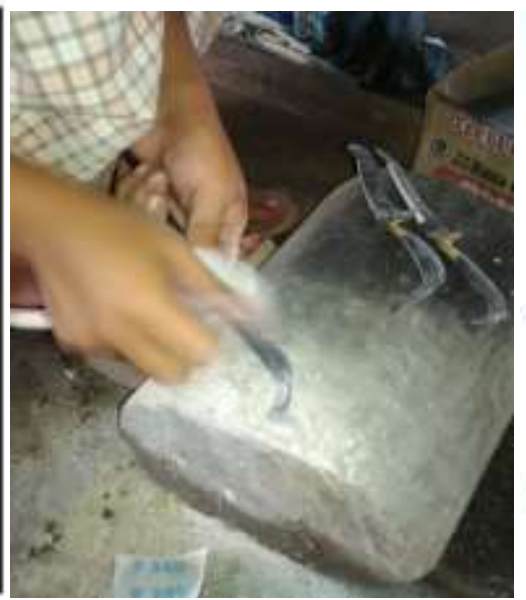

(b)

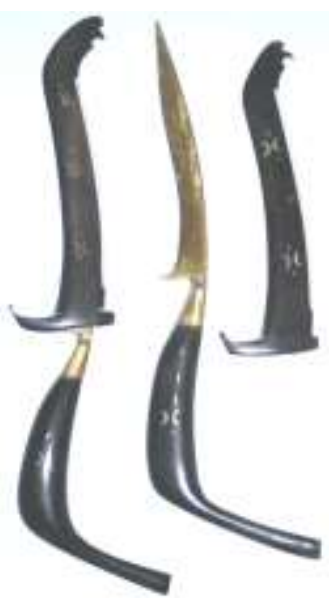

(c)

Figure 3. The blades of rencong produced from metal brass waste

The blades obtained from simple casting method were produce in relatively short time (Figure 3a). To produce a blade of rencong, the craftsmen only required approximately for three minutes, which was much shorter-time compared to the time needed to produce a single blade by traditional casting metal techniques with one hour. The Figure $3 b$ shows the finishing process manually by hands, and the Figure $3 \mathrm{c}$ displays the results of the finishing process. The marketing steps are not only sold in form of a souvenir, but also in a single blade. The following Figure 4 shows a souvenir form of rencong a blade, which is traded in local market.

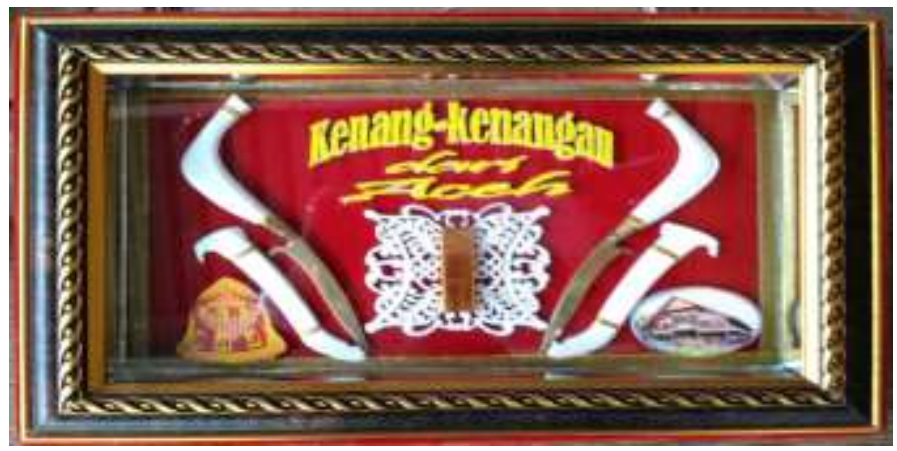

Figure 4. Rencong blades placed within a frame traded as a souvenir

\section{Conclusions}

In conclusions, the transferring technology of simple metal casting to the local craftsmen is effectively replaced the traditional metal casting. The use of melting furnace fueled by charcoal have been successfully melted the metal brass wastes in relatively high security, safety, and healthy, while the raw materials are accessible. The implementation of simple metal casting methods can increase the efficiency of productions by reducing the costs of productions, so this 
can increase the revenue of craftsmen. On the other hand, this technology is able to increase the quality of rencong souvenirs.

\section{Acknowledgment}

The authors would like to thank to the Directorate of Research and Community Services (DP2M) for its fund in program IbM, with community services program 2017. Gratitude is also given to the research institutions and community services of University of Syiah Kuala (LPPMUnsyiah) for the aid.

\section{REFERENCES}

[1] T. V. R. Rao, Metal casting: Principles and practice, India: New Age International, 2007.

[2] N. David, R. Heimann, D. Killick and M. Wayman, "Between Bloomery and Blast Furnace: Mafa Iron-Smelting Technology in North Cameroon," African Archaeological Review, vol. 7, no. 1, pp. 183-208, 1989.

[3] I. V. Kojo, A. Jokilaakso and P. Hanniala, "Flash Smelting and Converting Furnaces: A 50 Year Retrospect," JOM, vol. 52, no. 2, pp. 57-61, 2000.

[4] E. Sundari, "Rancang Bangun Dapur Peleburan Alumunium Bahan Bakar GAS," Jurnal Austenit, vol. 3, no. 1, pp. 17-26, 2011.

[5] G. A. Ikechukwu and P. N. Atanmo, "Development of An Improved Crucible Furnace Using Locally Sourced Materials for Teaching and Learning Purposes in Metallurgical Laboratory," Current Journal of Applied Science and Technology, vol. 26, no. 1, pp. 1-14, 2018.

[6] A. Z. Mubarak and Akhyar, "Perancangan dan Pembuatan Dapur Peleburan Logam dengan Menggunakan Bahan Bakar Gas (LPG)," Jurnal Teknik Mesin Unsyiah, vol. 1, no. 3, pp. 128-132, 2013.

[7] A. Leman, Tiwan, Widarto and A. Ardian, "Improving the Compact Crucible Furnace Performance by Adding Fins in Heating Chamber," In IOP Conference Series: Materials Science and Engineering, vol. 535, no. 1, p. 012011. IOP Publishing, 2019.

[8] B. Ginting, Rancang Dapur Peleburan untuk Melebur Aluminium dan Paduannya dengan Kapasitas 30 Kg, Medan: Departemen Teknik Mesin Fakultas Teknik Universitas Sumatera Utara, 2008.

[9] R. Magga, "Analisis Perancangan Tungku Pengecoran Logam (Non-Fero) sebagai Sarana Pembelajaran Teknik Pengecoran," JIMT, vol. 7, no. 1, pp. 54-60, 2010.

[10] H. Setiawan, "Proses Pembekuan Searah pada Produk Cor Propeler Kuningan," in Prosidiing Seminar Nasional Sains dan Teknologi ke-5 Fakultas Teknik Universitas Wahid Hasyim Semarang, vol. 1, no. 1, pp. 37-42, 2014.

[11] Supriyanto, "Analisis Coran Kuningan dari Limbah Rosokan dan Gram-Gram Sisa Permesinan untuk Komponen Permesinan," Jurnal Kompetensi Teknik, vol. 1, no. 2, pp. 49-56, 2010.

[12] W. R. Tschinkel, "Methods for Casting Subterranean Ant Nests," Journal of Insect Science, vol. 10, 88, pp. 1-17, (2010).

[13] J. Palmer, L. Savage, O. R. Ghita and K. E. Evans, "Sheet Moulding Compound (SMC) from Carbon Fibre Recyclate," Composites Part A: Applied Science and Manufacturing, vol. 41, no. 9, pp. 1232-1237, 2010.

[14] C. E. Sims and F. B. Dahle, "Effect of Aluminum on the Properties of Medium Carbon Cast Steel," Trans. Am. Foundrym. Soc, vol. 46, pp. 65-132, 1938.

[15] P. T. Craddock, Cast Iron, Fined Iron, Crucible Steel: Liquid Iron in the Ancient World, in P.T., Craddock and J., Lang. (eds) Mining and Metal Production through the ages. London: The British Museum Press, pp. 231-257, 2003. 
[16] Z. Milzam, Analisa Cacat Hasil Coran dari Bahan Kuningan Bekas untuk Pembuatan Souvenir Rencong Aceh, Banda Aceh: Fakultas Teknik Universitas Syiah Kuala, 2015.

[17] R. M. V. Darsa, Kerajinan Rencong di Desa Meunasah Blang Rnkecamatan Tanah Pasir Rnkabupaten Aceh Utara, Banda Aceh: Fakultas Teknik Universitas Syiah Kuala, 2015.

[18] E. Ristianingrum, Studi Tentang Keris Karya Suyanto (Kajian Tentang Estetika dan Proses Pembuatan), Surakarta: FKIP Universitas Sebelas Maret, 2006.

[19] Z. Xiaomei, "Research on Knife-Shaped Coins of the Yah State," Archaeology, vol. 9, 2005.

[20] L. Nickel, "Imperfect Symmetry: Re-Thinking Bronze Casting Technology in Ancient China." Artibus Asiae, vol. 66, no. 1, pp. 5-39, 2006. 